\title{
THE CHILLINGHAM CATTLE
}

\author{
By E. P. GEE
}

The last mention of the famous herd of Chillingham Cattle in the Journal of this Society was made in Part XVI published in April, 1932. At that time an appeal was being launched by three Trustees appointed for the purpose by the Council of the Zoological Society of London; and a lease for seven years at a rental of $£ 500$ per annum of the Park at Chillingham Castle in Northumberland was taken from the Earl of Tankerville, with the object of preserving the cattle. The present Farl, who succeeded to the title in 1931, was unable to maintain the herd at his own expense owing to the heavy and ever increasing burden of taxation. The Zoological Society of London contributed $£ 100$ annually for seven years, and the rest was found by public subscriptions.

Early in 1939, when the seven years' lease had expired, and various attempts had been made to place the wild cattle under national ownership without success, Chillingham Wild Cattle Association, Ltd., was formed. This is a non-profit-making undertaking with a Council of eight distinguished persons, with the Earl of Tankerville himself as Life President. The public are invited to join at a membership fee of one guinea per annum, which entitles them to the privilege of visiting the wild cattle free of charge with two guests, though at all times strictly in company with the keeper.

Within a short time sufficient people became members to enable the herd to be maintained, under conditions of the strictest economy. It was then estimated that at the 1939 price level, a total of 300 members would enable the scheme to go forward ; but the present membership (at 30th May, 1950), is only 251-considerably below that required to ensure with absolute certainty the preservation of these extremely valuable and interesting animals. It is, however, gratifying to note that the ending of petrol rationing has increased the number of visits from the general public, who pay one shilling per head. The cattle may be visited between the hours of 10 a.m. and 5 p.m. on weekdays, and 2 p.m. and 5 p.m. on Sundays; on Tuesdays (the keeper's day off) and from 1st October, to 1st April prior notification should be given by intending visitors.

For the thirty years prior to 1947 the strength of the herd had been fairly constant at about 35 to 40 head. (The lowest recorded total had been that of the year 1692 , when there were 


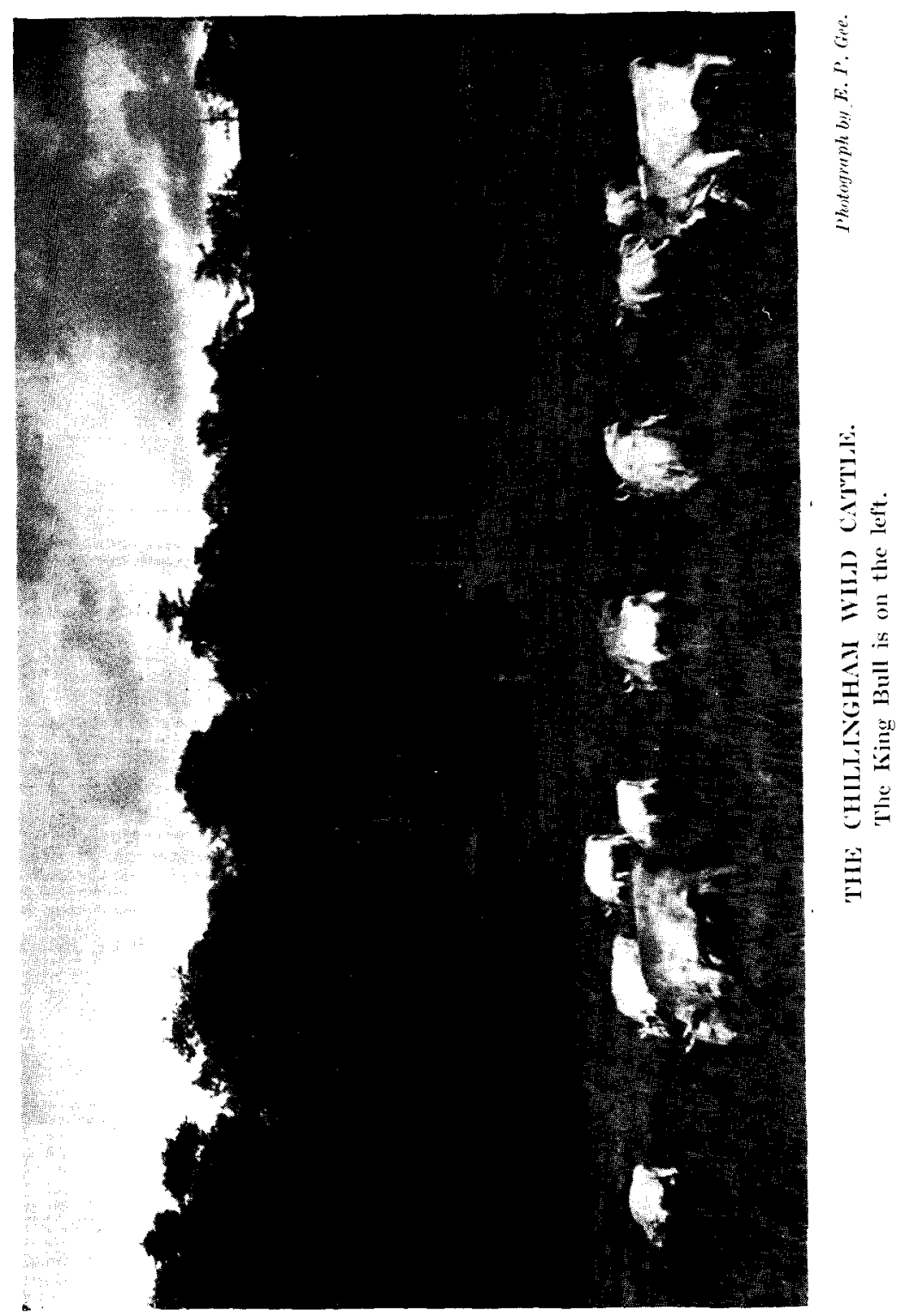


16 " beastes" and 12 steers, totalling only 28 animals.) Then in the beginning of 1947 came the most severe winter within living memory in Northumberland, with snow drifts in the Park of Chillingham up to 40 feet deep. In spite of all efforts to save the cattle by supplying fodder at a time of great scarcity of feeding stuffs, when the blizzards and snow storms had ceased it was found that 20 out of the 33 cattle had perished.

Of the 13 survivors, 8 were cows, 5 were bulls, and none of them were youngsters. For 18 months or so no calf was born, presumably because of general debility after the critical time through which they had passed. It was even considered that the king bull might have become infertile, and therefore might have to be destroyed in order to give another bull a chance to save the herd from extinction. Then two bull calves arrived, followed later by another bull calf, thus ending the doubt concerning the bull's fertility, but raising further fears for the survival of the herd. Fortunately, however, four heifers have been born since then, and the herd now consists of 3 bulls, 7 cows, 2 bull calves, and 4 heifer calves; and the cattle may now be considered to be making a "come-back".

I was recently able to visit the Park of Chillingham and was sufficiently impressed by the cattle to repeat the visit three times in a holiday lasting only five days. The primeval forest conditions, the magnificent scenery and the cattle themselves are such as to arouse intense interest not only in zoologists, naturalists, and cattle breeders, but also in the general public. I was privileged to see the latest newly born calf hiding itself in the bracken to await its mother's return later in the day. Beneath the tree in which I sat, concealed and in safety, I witnessed a fight between two bulls at a distance of a few feet only. I saw fallow deer at close quarters start up from the bracken, and the cattle career wildly away at the sight. I was able to approach the herd quite close, both with the keeper, and by myself after obtaining special permission to do so.

Whatever may be their exact origin, there is no doubt that these cattle have been in the Chillingham Park since it was enclosed by a wall about the year 1240, and that as such they are unique. They are a National Monument of historical as well as of æsthetic and biological interest and it would be a national calamity if ever they were allowed to become extinct.

Appointments to view the herd, and applications for membership should be addressed to : The Secretary, Chillingham Wild Cattle Association, Ltd., Estate Office, Chillingham, Alnwick, Northumberland (Telephone: Chatton 213). 